Provided for non-commercial research and education use. Not for reproduction, distribution or commercial use.

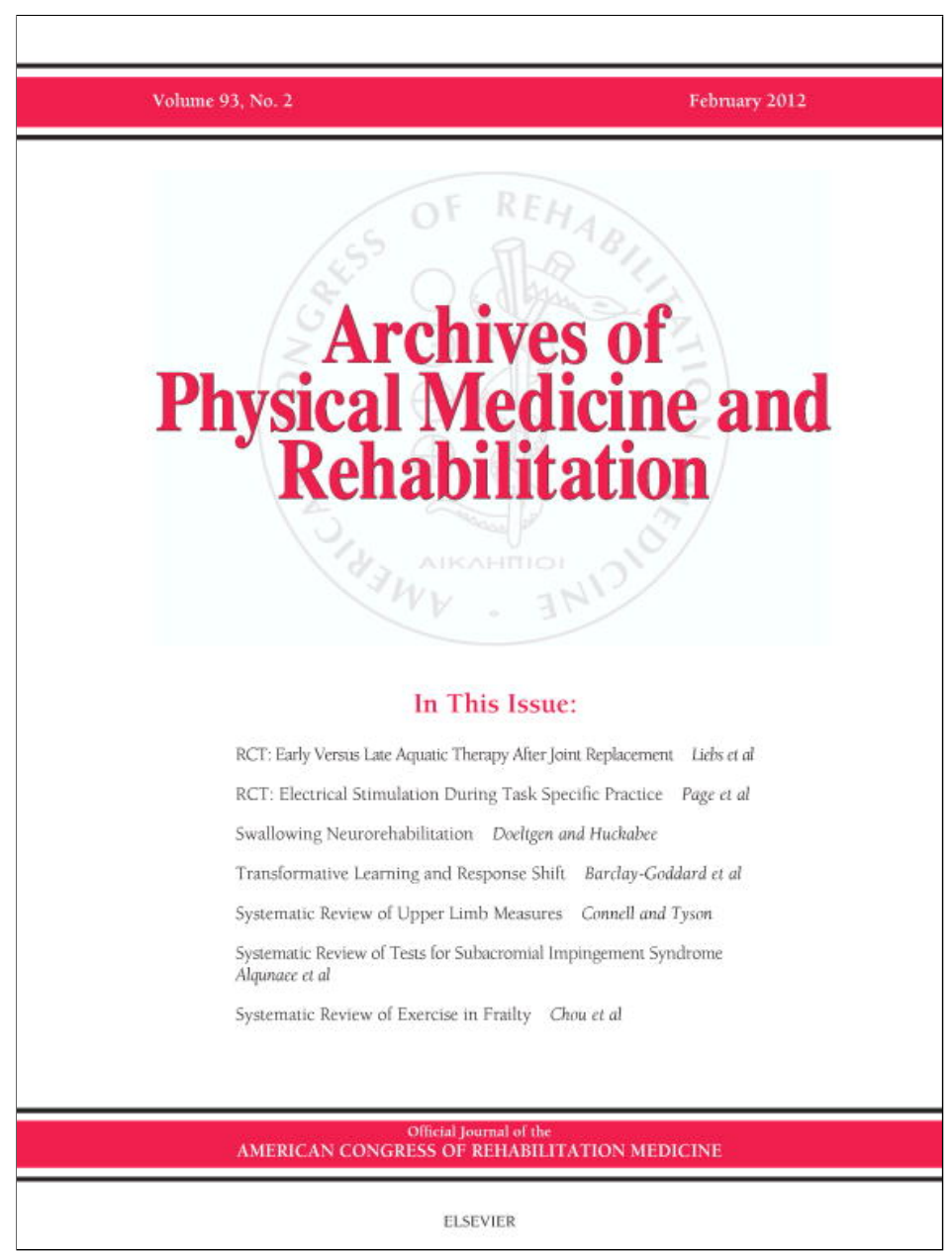

This article appeared in a journal published by Elsevier. The attached copy is furnished to the author for internal non-commercial research and education use, including for instruction at the authors institution and sharing with colleagues.

Other uses, including reproduction and distribution, or selling or licensing copies, or posting to personal, institutional or third party websites are prohibited.

In most cases authors are permitted to post their version of the article (e.g. in Word or Tex form) to their personal website or institutional repository. Authors requiring further information regarding Elsevier's archiving and manuscript policies are encouraged to visit:

http://www.elsevier.com/copyright 


\section{Clinical Reality of Measuring Upper-Limb Ability in Neurologic Conditions: A Systematic Review}

\section{Louise A. Connell, PhD, Sarah F. Tyson, PhD}

ABSTRACT. Connell LA, Tyson SF. Clinical reality of measuring upper-limb ability in neurologic conditions: a systematic review. Arch Phys Med Rehabil 2012;93:221-8.

Objective: To review the psychometric properties and clinical utility of upper-limb measurement tools in people with neurologic conditions to provide recommendations for practice.

Data Sources: MEDLINE, CINAHL, EMBASE, PEDro, and AMED.

Study Selection: Independent reviewers searched, selected, and extracted data from articles that assessed reliability, validity, ability to detect change, and clinical utility of measures of the upper limb in adult neurologic conditions.

Data Extraction: Measures with good psychometrics and 8 or higher (out of 10) clinical utility scores were recommended.

Data Synthesis: The searches identified 31 measures of the upper limb. However, only 2 measures fulfilled all of the psychometric and clinical utility criteria; the Box and Block Test and the Action Research Arm Test.

Conclusions: The Box and Block and the Action Research Arm Tests produce robust data and are feasible for use in clinical practice. Future development of new or existing measures should ensure the construct and content validity of the measure is clearly identified, standardized guidelines are easily available, and ensure that it is individualized and contemporary. Attention to measures of upper-limb activity for people who are unable to grip objects is also needed.

Key Words: Outcome assessment (health care); Psychometrics; Rehabilitation; Reproducibility of results; Upper extremity.

(C) 2012 by the American Congress of Rehabilitation Medicine

$\mathbf{O}$ BJECTIVE MEASUREMENT is a core part of rehabilitation to the extent that clinical guidelines and professional bodies explicitly state that standardized measurement tools should be used. ${ }^{1-3}$ However, guidelines rarely specify which measures should be used.4-6 Consequently, many researchers and health care professionals are uncertain which to use and report lack of time, information, and knowledge to make informed choices. ${ }^{7-10}$ Hence, implementation into clinical practice is patchy and inconsistent and a wide variety of outcome measures are used in rehabilitation research. Inconsistency in the outcomes used in clinical trials prevents com-

From the Clinical Practice Research Unit, University of Central Lancashire, Preston (Connell); School of Health, Sport and Rehabilitation Science, University of Salford, Salford, (Tyson), UK.

No commercial party having a direct financial interest in the results of the research supporting this article has or will confer a benefit on the authors or on any organization with which the authors are associated.

Reprint requests to Louise A. Connell, Clinical Practice Research Unit, 415 Brook Building, School of Health, Preston, UK, PR12HE, e-mail: laconnell@uclan.ac.uk. 0003-9993/12/9302-00063\$36.00/0

doi:10.1016/j.apmr.2011.09.015 parison between trials, especially meta-analyses, and is a historic and on-going problem that limits the development of the evidence base for rehabilitation. ${ }^{11-13}$

This article is part of a series that systematically reviews the psychometric properties and clinical utility (the feasibility of using measurement tools in clinical practice) to identify those that would be most suitable for use in practice. It considers measures of upper-limb impairment and activity.

Upper-limb impairments and activity limitations are a frequent consequence of neurologic conditions, which impact negatively on participation and quality of life ${ }^{14}$ and are therefore a frequent focus of rehabilitation. Many upper-limb measures have been published for stroke and their psychometric properties reviewed previously. ${ }^{15-18}$ However, other neurologic conditions and the feasibility of the measures have received scant consideration. This article combines a review of the psychometrics with the clinical utility and includes measures of all neurologic conditions.

\section{METHODS}

The method developed for this project has been reported in detail in the reviews of previous domains ${ }^{19,20}$ and is reproduced here with the aspects that are specific to the review of measures of the upper limb.

\section{Study Identification and Selection}

Electronic databases (MEDLINE, CINAHL, EMBASE, PEDro, and AMED) were searched from their inception to September 2009 using the following keywords:

outcome or measure or measurement tool or assessment or test and upper limb or arm or upper extremity and

stroke or cerebrovascular accident or hemiplegia or hemi\$ or parkinson\$ or multiple sclerosis or head injury or brain injury or guillan-barre or motor neurone disease or amyotrophic lateral sclerosis

All searches were limited to English language and human adults. We excluded articles that involved people with noncerebral lesions (eg, spinal cord injuries or peripheral nerve lesions) and articles which measured psychometric properties other than those listed in the data extraction section below. Measures which were not specific to the upper limb were also excluded. This included generic measures, which apply to the whole body, such as strength or range of movement, and measures of shoulder subluxation or ataxia, because these were subject to a separate review.

Other exclusions were measures in which only 1 psychometric property had been assessed and so clearly we had insufficient information to recommend for clinical use. Composite

List of Abbreviations STREAM $\begin{gathered}\text { Stroke Rehabilitation Assessment of } \\ \text { Movement }\end{gathered}$ 
measures, which included the upper limb as part of a wider assessment of general motor function or data from different impairments and activity limitations from which data on the upper limb domains could not be extracted, were excluded. Such tools give an overall indication of the patient's status. This is useful when used as an outcome in research but it is of limited value in clinical practice. In the clinical context, more detail of the specific impairments and activity limitations is needed to identify problems, monitor progress, and plan treatments.

Instrumented measures or devices, which had no information about how the device could be obtained, or insufficient information about the operating instructions to be obtained or developed, or was clearly not commercially available, were excluded.

Two reviewers (L.C. and S.T.) independently assessed the titles and abstracts of articles identified by the search. Snowballing techniques were used to ensure that all published literature on the tools had been identified. We hand searched the reference lists of selected tools and previous reviews, undertook specific searches of the databases listed above for the tests (and their authors) identified from the screening of titles and abstracts and contacted the authors for further details when required.

\section{Data Extraction}

Data about the psychometric properties and clinical utility of the measures were extracted from the selected articles by volunteer neurologic physiotherapists from the National Health Service Trusts across the Northwest of England using standardized instructions and data extraction forms and with support from the authors. They worked in pairs, each reviewing a maximum of 6 articles. After reviewing each article individually, the physiotherapists met with their partner to agree a consensus about the data extracted. The data for each locality was collated and then checked and independently analyzed by L.C. and S.T. to assess the clinical utility and psychometric properties. Where the results of the analysis differed, disagreements were resolved through discussion. A third person was available to arbitrate if agreement could not be reached. Clinical utility refers to the practical details of using a measurement tool and was scored against criteria developed in consultation with neurologic physiotherapists in Northwest England and drawing on the literature on the barriers and facilitators to implementation of measurement tools in clinical practice. ${ }^{9-11}$ The selected issues were considered key to the feasibility of using a measurement tool in clinical practice, with the criteria representing categories that would influence clinicians' decision about whether to use the measures and the weighting were clinically meaningful important. The criteria were as follows:

- Time taken to administer, analyzes, and interpret the measurement tool:

$3 \leq 10 \mathrm{~min} \quad 2=10-30 \mathrm{~min} \quad 1=30-60 \mathrm{~min} \quad 0 \geq 1 \mathrm{~h}$

- Cost

$3 \leq £ 100 \quad 2=£ 100-£ 500 \quad 1=£ 500-£ 1000 \quad 0 \geq £ 1000$ or unknown

- Does the measurement tool need specialist equipment and training to use?

$2=$ no $1=$ yes, but simple and clinically feasible $0=$ yes and not clinically feasible/unknown

- Is the measurement tool portable? Can it be taken to the patient?

$2=$ yes easily (can fit in a pocket) $1=$ yes (in a briefcase or trolley) $0=$ no or very difficult
These scores were summated with a maximum score of 10 . Measurement tools that scored less than 8 were considered infeasible for use in clinical practice and were rejected at this stage. This cutoff was decided by the participating clinical physiotherapists (who were involved in the data extraction) and hence is empirically justified by clinicians who would make decisions about using such measures in clinical practice. Those measures which scored 8 and above were considered feasible and their psychometric properties were assessed to identify those which would provide robust data, as follows. The psychometric properties assessed were reliability (interrater and test-retest), concurrent or criterion related validity, and ability to detect change. The accepted methods to assess these properties were:

- For reliability: intraclass correlations (for parametric data) and kappa statistics (for nonparametric data).

- For validity: (parametric or nonparametric) correlation coefficients.

- For ability to detect change: measurement error, standardized response mean, standardized error of measurement, limits of agreement, and minimal detectable change.

The strength of the psychometric properties were assessed as recommended $^{21}$ :

+ weak reliability or validity $=$ scores of $0.4-0.6$;

++ moderate reliability or validity $=$ scores of $0.6-0.8$

+++ good reliability or validity $=$ scores of $\geq 0.8$

As data from the tests of ability to detect change are nonstandardized, the acceptable (or unacceptable) limits were not specified but considered individually. For ordinal scales, the scaling properties of a measure were also considered through an assessment of the hierarchy (coefficients of scalability or reproducibility), Rasch analysis, factor analysis, or internal consistency.

The measurement properties were summarized in a way that may aid selection of an instrument. A measurement tool needed to obtain good scores for reliability and validity and have some information about the ability to detect change before it could be recommended for use in clinical practice.

\section{RESULTS}

The searches identified 31 measures of the upper limb. However, 19 measures were subsequently rejected. Four were composite measures where it was not possible to extract information on subscales of the upper limb, ${ }^{22-25} 2$ measured other constructs such as strength, ${ }^{26,27} 12$ did not meet the clinical utility criteria, ${ }^{28-39}$ (table 1 ) and 1 had only 1 psychometric property tested. ${ }^{40}$

Two versions of the Stroke Rehabilitation Assessment of Movement (STREAM) (the original and simplified versions ${ }^{41,42}$ ) scored 10 for clinical utility; however, only the results for the simplified STREAM are shown as it is quicker and simpler and therefore has greater clinically utility than the original version. To aid comparison, the results were categorized according to the International Classification of Functioning, Disability and Health ${ }^{43}$ into measures of impairment (in this case, dysfunction of the hand or upper-limb system, eg, grips, grasps, and dexterity), upper-limb activity limitation (or activity in every day life), and participation. The remaining 11 selected measures evaluated upper-limb impairments $(n=4)$ and activity in everyday life $(n=7)$. All had some assessment of the concurrent or criterion-related validity and all but the Abilhand ${ }^{44}$ had an assessment of test-retest reliability (tables 2 and 3). All the measures showed good test-retest reliability while validity was moderate or good. Fewer tests had an evaluation of intertester reliability ${ }^{41,44,50-52}$ and the ability to 
Table 1: Clinical Utility of Upper-Limb Measures

\begin{tabular}{|c|c|c|c|c|c|}
\hline Measurement Tool & $\begin{array}{l}\text { Time to } \\
\text { Complete }\end{array}$ & Cost & Portability & $\begin{array}{l}\text { Need for Specialist } \\
\text { Equipment }\end{array}$ & $\begin{array}{c}\text { Total } \\
(\max =10)\end{array}$ \\
\hline Fitts Reaching test ${ }^{45 *}$ & 3 & 3 & 2 & 2 & 10 \\
\hline Reaching Performance Scale ${ }^{28}$ & 3 & 3 & 2 & 2 & 3 \\
\hline Observation of upper-limb movements ${ }^{29}$ & 3 & 3 & 1 & 2 & 3 \\
\hline Frenchay Arm Test ${ }^{30}$ & 2 & 3 & 1 & 1 & 7 \\
\hline Box and Block test ${ }^{51 *}$ & 3 & 3 & 1 & 1 & 8 \\
\hline Nine-Hole Peg Test ${ }^{46 *}$ & 3 & 3 & 1 & 1 & 8 \\
\hline TEMPA $^{31}$ & 1 & 3 & 1 & 1 & 6 \\
\hline $\begin{array}{l}\text { Wolf Motor Function Test (also known as the } \\
\text { Emory Motor Test) }\end{array}$ & 1 & 3 & 1 & 1 & 6 \\
\hline Jebsen Hand Tests ${ }^{33}$ & 1 & 2 & 1 & 1 & 5 \\
\hline Modified Jebsen Hand Test ${ }^{34}$ & 2 & 3 & 1 & 1 & 7 \\
\hline (Modified) Arm Motor Ability Test ${ }^{35}$ & 1 & 3 & 1 & 1 & 6 \\
\hline Action Research Arm Test ${ }^{52 *}$ & 3 & 3 & 1 & 1 & 8 \\
\hline Abilhand ${ }^{44 *}$ & 2 & 3 & 2 & 2 & 9 \\
\hline Motor Activity $\log ^{47 *}$ & 3 & 3 & 2 & 2 & 10 \\
\hline Accelerometry/activity monitors ${ }^{36,37}$ & 0 & 0 & 2 & 0 & 2 \\
\hline Rivermead Motor Assessment-arm section ${ }^{48 *}$ & 2 & 3 & 2 & 2 & 9 \\
\hline Motor Status Score ${ }^{49 *}$ & 2 & 3 & 1 & 2 & 8 \\
\hline Chedoke Arm \& Hand Action Inventory ${ }^{38}$ & 2 & 3 & 1 & 1 & 7 \\
\hline Sollerman hand function test $\mathrm{t}^{50 *}$ & 3 & 3 & 1 & 1 & 8 \\
\hline STREAM-upper-limb section ${ }^{41 *}$ & 3 & 3 & 3 & 2 & 10 \\
\hline Simplified STREAM-upper-limb section ${ }^{42 *}$ & 3 & 3 & 3 & 2 & 10 \\
\hline Motor Assessment Scale (upper limb section) ${ }^{39}$ & 2 & 3 & 1 & 1 & 7 \\
\hline
\end{tabular}

Abbreviation: TEMPA, Test d'Evaluation de la performance des Membres Supérieurs des Personnes Agées.

* Indicates those measures that scored more than 8 of 10 on their clinical utility and were deemed feasible for use in clinical practice.

detect change. ${ }^{46,51-52}$ In all cases, when tested, the intertester reliability was found to be good; however, none of the measures of upper-limb activity had data demonstrating how much change in score would be needed to demonstrate a true change in performance.

Only 2 measures fulfilled all of the psychometric criteria; both measured upper-limb impairment: the Box and Block test $^{51}$ and the Action Research Arm Test. ${ }^{52}$ The validity of the Box and Block test has been tested on patients with stroke, multiple sclerosis, traumatic brain injury, and other (unspecified) neurologic pathologies. It has a well-established normative dataset and has also been (favorably) evaluated in the healthy and disabled elderly. ${ }^{51,53}$ The Action Research Arm Test has only been validated on patients with stroke. Neither of the tests have been tested in people with Parkinson's Disease or ataxia. Both are briefly described below.

Box and Block test. ${ }^{51}$ The Box and Block test is a functional performance test of basic manual dexterity, which requires the patient to pick up and transfer small blocks from 1 side to the other of a portioned box. The number of blocks transferred from 1 side of the box to another in 60 seconds is recorded. The minimum detectable difference is 6 blocks. As the patient needs to be able to grip a block and lift the arm, it would have a floor effect for patient with severe paresis. The clinically important change has not been specified beyond the minimal detectable difference.

The Action Research Arm Test. The Action Research Arm Test was developed by Lyle ${ }^{52}$ based on the upper-extremity function test of Carroll. ${ }^{26}$ It is an ordinal scale of 19 items in 4 subsections: grasp, grip, pinch, and gross movement (large scale movements of the whole arm). The grasp and pinch subscales each have 6 items, the grip subscale has 4 items, and the gross movement has 3 items. The maximum score is 57 . The Action Research Arm Test has been shown to be reliable, but studies have primarily been undertaken in single sites. Difficulty with the interpretation of the scoring (eg, defining an "abnormally long time" to complete tasks) led to more detailed operational instructions being published. ${ }^{54}$ It forms a true Guttman scale, indicating that it is unidimensional, hierarchical, and there is no redundancy in the included items, thus minimizing the administration time. ${ }^{55}$ The minimal detectable difference is 6 points (out of 57) suggesting that the test may detect change, and it does include some items, which do not require the patient to be able to make a grip (the gross movement section), so it would have a lower floor than the Box and Block test. The clinically important change has not been specified beyond the minimal detectable difference.

\section{DISCUSSION}

Only 2 measures of the upper limb fulfilled the criteria for use in clinical practice: the Action Research Arm Test and the Box and Block test. The minimal detectable change and interrater reliability were the psychometric properties that received the least attention; yet, these are vital for the clinical interpretation of change over time, when testing is likely to be carried out by different personnel and one needs to judge whether a change in score represents a true change in ability. Future measurement tool development should include assessment of these psychometric properties. Like all areas of neurologic rehabilitation, the measures of upper-limb problems were primarily designed for, and tested on, people with stroke. Although the Box and Block test has been evaluated for other neurologic conditions, the Action Research Arm Test has only be evaluated in stroke. It cannot be assumed that the items included in this test (and other ordinal scales) are valid for other neurologic conditions, such as Parkinson's disease or ataxia, nor that the hierarchical structure is the same for all conditions. 
Table 2: Psychometric Properties of Measures of the Upper Limb

\begin{tabular}{|c|c|c|c|}
\hline Measurement Tool & $\begin{array}{c}\text { Psychometric Property } \\
\text { Tested }\end{array}$ & Subjects & Results \\
\hline \multicolumn{4}{|l|}{$\begin{array}{l}\text { Upper-Limb Impairments-Hand } \\
\text { (grips, grasps, and } \\
\text { dexterity) }\end{array}$} \\
\hline Fitts Reaching test ${ }^{69}$ & $\begin{array}{l}\text { Validity } \\
\text { Test-retest reliability }\end{array}$ & $\begin{array}{l}18 \text { stroke patients }(8-52 d \\
\text { poststroke) } \\
\text { Mean age } \pm S D, 76 y \pm 8,7 \\
\text { Men/women: } 8 / 10\end{array}$ & $\begin{array}{l}\text { Validity wrt } \\
\text { Action Research Arm Test } r=0.27-0.54 \\
\text { Hand-Motor Assessment Scale } r=0.64 \\
\text { Reliability ICC }=0.74-0.95\end{array}$ \\
\hline Box and Block test ${ }^{70}$ & Validity & $\begin{array}{l}15 \text { stroke patients ( }>1 \mathrm{y} \text { poststroke) } \\
\text { Mean age } \pm S D, 47 \pm 14 \mathrm{y} \\
\text { Men/women: } 10 / 5\end{array}$ & Validity wrt grip strength $r=0.87$ \\
\hline Box and Block test ${ }^{71}$ & Validity & $\begin{array}{l}104 \text { subjects } \\
\text { Strokes }=51 \% \text {, } \\
\text { Other (various pathologies) }=49 \% \\
\text { Mean age } \pm \text { SD, } 74 \pm 7.4 y\end{array}$ & Validity wrt TEMPA $r=-0.73$ to 0.78 \\
\hline Box and Block test ${ }^{73}$ & $\begin{array}{l}\text { Test-retest reliability } \\
\text { Ability to detect } \\
\text { change }\end{array}$ & $\begin{array}{l}62 \text { stroke patients; median } 8 \mathrm{mo} \\
\text { poststroke } \\
\text { Mean age } \pm \text { SD, } 61 \pm 9.9 \mathrm{y}\end{array}$ & $\begin{array}{l}\text { Test-retest reliability } \mathrm{ICC}=0.93-0.98 \\
\mathrm{MDC}=6 \text { blocks (weak hand), } 8 \text { blocks } \\
\text { (sound hand) }\end{array}$ \\
\hline Nine-Hole Peg Test ${ }^{27}$ & Validity & $\begin{array}{l}38 \text { acute strokes } \\
\text { Mean } \pm S D, 11 \pm 9 d \text { poststroke } \\
\text { Mean age, } 67 \mathrm{y} ; 17 \text { men }\end{array}$ & Validity wrt grip strength $r=0.71$ \\
\hline Nine-Hole Peg Test ${ }^{74}$ & Validity & $\begin{array}{l}43 \text { multiple sclerosis patients; } 13 \\
\text { women } \\
\text { Mean age, } 46 y \\
\text { Mean duration, } 15 y \\
\text { Mean Extended Disability Status } \\
\text { Score, } 7.0\end{array}$ & $\begin{array}{l}\text { Validity wrt Jebsen Hand Function } \\
\quad r=0.83-0.95 \\
\text { Wrt TEMPA } r=0.79-0.90\end{array}$ \\
\hline Nine-Hole Peg Test ${ }^{73}$ & $\begin{array}{l}\text { Test-retest reliability } \\
\text { Ability to detect } \\
\text { change }\end{array}$ & $\begin{array}{l}62 \text { stroke patients; median } 8 \mathrm{mo} \\
\text { poststroke } \\
\text { Mean age } \pm S D, 61 \pm 9.9 \mathrm{y}\end{array}$ & $\begin{array}{l}\text { Test-retest reliability } \mathrm{ICC}=0.85-0.89 \\
\mathrm{MDC}=32.8 \mathrm{~s} \text { (more affected hand), 6.2s } \\
\quad(\text { less affected hand) }\end{array}$ \\
\hline $\begin{array}{l}\text { Action Research Arm } \\
\text { Test }^{75,76}\end{array}$ & $\begin{array}{l}\text { Test-retest reliability } \\
\text { Inter-rater reliability } \\
\text { Ability to detect } \\
\quad \text { change }\end{array}$ & $\begin{array}{l}20 \text { chronic strokes; median } 3.6 y \\
\text { poststroke; } 13 \text { men } \\
\text { Median age, } 59 y\end{array}$ & $\begin{array}{l}\text { MDC (limits of agreement })=6 \\
\text { Intrarater reliability } I C C>0.98 \\
\text { Interrater reliability } I C C>0.98\end{array}$ \\
\hline Action Research Arm Test ${ }^{77}$ & $\begin{array}{l}\text { Validity } \\
\text { Inter-rater reliability }\end{array}$ & $\begin{array}{l}50 \text { stroke patients; median } 55 \mathrm{~d} \\
\text { poststroke (range, } 8-535 \text { ) } \\
\text { Mean age } \pm S D, 5 \pm 13 y\end{array}$ & $\begin{array}{l}\text { Validity wrt } \\
\text { - Motor Assessment Scale } r=0.96 \\
\text { - Motricity Index } r=0.87 \\
\text { - Motor Assessment Chart } r=0.94\end{array}$ \\
\hline Action Research Arm Test ${ }^{55}$ & Validity & $\begin{array}{l}53 \text { stroke patients, } 2 \text { wk poststroke } \\
\text { Mean age } \pm S D, 69 \pm 9 y \\
\text { Men/women: } 25 / 28\end{array}$ & Validity wrt Fugl-Meyer test $r=0.91-0.94$ \\
\hline Action Research Arm Test ${ }^{78}$ & Validity & $\begin{array}{l}12 \text { community-dwelling stroke } \\
\text { patients; mean } 70 \text { mo poststroke } \\
\text { Mean age, } 57 \pm 7 y \\
\text { Men/women: } 8 / 4\end{array}$ & $\begin{array}{l}\text { Validity wrt Wolf Motor Function Test } \\
\qquad \begin{aligned} r=0.96, \text { wrt Motor Activity Log } \\
r=0.91-0.97\end{aligned}\end{array}$ \\
\hline Action Research Arm Test ${ }^{79}$ & Validity & $\begin{array}{l}104 \text { stroke patients } \\
\text { Mean } \pm S D, 16 \pm 9 d \text { poststroke } \\
\text { Mean age } \pm S D, 72 \pm 13 y \\
\text { Men/women: } 43 / 61\end{array}$ & $\begin{array}{l}\text { Validity wrt Fugl-Meyer Assessment } \\
\qquad r=0.77-0.87\end{array}$ \\
\hline
\end{tabular}


Table 2: Psychometric Properties of Measures of the Upper Limb (Cont'd)

\begin{tabular}{|c|c|c|c|}
\hline Measurement Tool & $\begin{array}{c}\text { Psychometric Property } \\
\text { Tested }\end{array}$ & Subjects & Results \\
\hline \multicolumn{4}{|l|}{$\begin{array}{l}\text { Upper-Limb Activity in } \\
\text { Everyday Life }\end{array}$} \\
\hline Abilhand $^{44}$ & Validity & $\begin{array}{l}103 \text { chronic stroke patients }(>6 \mathrm{mo}) \\
\text { All independent in domestic } \\
\text { environment } \\
\text { Mean age, } 63 y \text { (range, } 24-84 \text { ) } \\
\text { Men/women: } 64 / 39\end{array}$ & $\begin{array}{l}\text { Validity } \\
\text { wrt grip strength } r=056 \\
\text { wrt Box and Block test } r=0.598 \\
\text { wrt Fugl-Meyer Assessment (Upper } \\
\quad \text { Limb) } r=0.73\end{array}$ \\
\hline Motor Activity Log ${ }^{66}$ & $\begin{array}{l}\text { Validity } \\
\text { Ability to detect } \\
\text { change }\end{array}$ & $\begin{array}{l}56 \text { chronic strokes } \\
\text { Median years poststroke, } 3.2 \text { (IQR } \\
2.1-5.1 \text { ) } \\
\text { Median age, } 61 \mathrm{y} \\
\text { Men/women: } 32 / 24\end{array}$ & $\begin{array}{l}\text { Validity wrt Action Research Arm Test } \\
\quad r=0.63 \\
\text { Limits of agreement }< \pm 1 \text { point }\end{array}$ \\
\hline Motor Activity $\log ^{37}$ & Validity & $\begin{array}{l}20 \text { stroke patients }>1 y \text { poststroke } \\
\text { Mean age } \pm S D, 62 \pm 20 y \\
\text { Men/women: } 12 / 8\end{array}$ & Validity wrt accelerometry $r=0.74$ \\
\hline Motor Activity Log 65 & $\begin{array}{l}\text { Validity } \\
\text { Test-retest reliability }\end{array}$ & $\begin{array}{l}\text { Validity study } 41 \text { stroke patients } \\
\quad(20 \text { constraint therapy, } 20 \text { control) } \\
\text { Mean age, } 51 y \text { and } 55 y \text {, respectively } \\
\text { Men/women: } 27 / 14 \\
\text { Reliability study } 27 \text { stroke patients } \\
\text { Mean age } \pm S D, 60 \pm 11 y \\
\text { Men/women: } 21 / 6\end{array}$ & $\begin{array}{l}\text { Validity wrt accelerometry } r=0.7-0.91 \\
\text { Test-retest reliability } r=0.91\end{array}$ \\
\hline Rivermead Motor & Validity & 107 subacute stroke patients & Validity wrt FIM motor $r=0.47$ \\
\hline Assessment-arm section ${ }^{80}$ & $\begin{array}{l}\text { Ability to detect } \\
\text { change }\end{array}$ & $\begin{array}{l}\text { Mean age } \pm S D, 62 \pm 13 y \\
\text { Median time since stroke, } 2 \mathrm{mo}\end{array}$ & Standardised response mean $=0.60$ \\
\hline $\begin{array}{l}\text { Rivermead Motor } \\
\text { Assessment-arm section }\end{array}$ & Validity & $\begin{array}{l}36 \text { participants with stroke } \\
\text { Age }=15-77 y \\
\text { Men/women: } 24 / 12\end{array}$ & $\begin{array}{l}\text { Validity wrt arm section of Motricity } \\
\text { Index at } 6,12 \text {, and } 18 \mathrm{wk} \text { after stroke } \\
r=0.73-0.76\end{array}$ \\
\hline Motor Status Score ${ }^{49}$ & Validity & $\begin{array}{l}18 \text { consecutive stroke patients } \\
\text { admitted for acute rehabilitation }\end{array}$ & $\begin{array}{l}\text { Validity wrt Fugl-Meyer Assessment } \\
\qquad r=0.96\end{array}$ \\
\hline $\begin{array}{l}\text { Sollerman hand function } \\
\text { test }^{50}\end{array}$ & $\begin{array}{l}\text { Test-retest reliability } \\
\text { Inter-rater reliability }\end{array}$ & $\begin{array}{l}24 \text { chronic strokes } \\
\text { Mean time poststroke, 30mo } \\
\text { Mean age, } 60 \mathrm{y}\end{array}$ & $\begin{array}{l}\text { Test-retest reliability ICC }>0.96 \\
\text { Interrater reliability ICC }>0.92\end{array}$ \\
\hline Simplified STREAM ${ }^{82}$ & $\begin{array}{l}\text { Validity } \\
\text { Test-retest reliability }\end{array}$ & $\begin{array}{l}50 \text { stroke inpatients } \\
\text { Mean } 19 \mathrm{~d} \text { poststroke } \\
\text { Mean age } \pm S D, 62 \pm 12 \mathrm{y} \\
\text { Men/women: } 36 / 14\end{array}$ & $\begin{array}{l}\text { Validity wrt Fugl-Meyer Motor Scale } \\
\quad r=0.91 \\
\text { Test-retest reliability ICC }=0.96\end{array}$ \\
\hline
\end{tabular}

Abbreviations: ICC, intraclass correlation coefficient; IOR, interquartile range; MDC, minimal detectable change; $r$, correlation coefficient; TEMPA, Test d'Evaluation de la performance des Membres Supérieurs des Personnes Agées; UL, upper limb; wrt, with respect to.

Both the recommended measures evaluate upper-limb impairment and are proxy measures of activity in that patients who scored more highly tend to be able to use their hand and upper limb more in everyday life. ${ }^{56}$ However, none of the direct measures of upper-limb activity in everyday life met the criteria for clinical use because evaluation of interrater reliability and ability to detect change were incomplete. It would be desirable to be able to directly measure upper-limb activity in clinical practice and in clinical trials because most patient goals are vouched in terms of what an individual can, or cannot do, in their daily lives. However, the choice of items to measure is a challenge. Given the primacy of patient-centered rehabilitation, there is a clear need to accurately and robustly measure activities that are meaningful and important to an individual. However, the more individualized an activity or treatment goal, the less generalizable it is likely to be, which defies standardization in an objective measurement tool. Researchers have attempted to overcome this by reducing the items to generic, proxy items (eg, the Action Research Arm Test ${ }^{52}$ and Rivermead Stroke Assessment [arm section] ${ }^{48}$ ) but this, inevitably, has limited meaningfulness for individual patients. An alternative approach is to include a large battery of items (eg, the Motor Activity $\log ^{47}$ ), but this risks redundancy of items. A possible way forward may be to develop a bank of standardized, objective items which can then be selected individually but scored using generic methods, building on methods such as Goal Attainment Scaling ${ }^{57}$ and the Canadian Occupational Performance Measure. ${ }^{58}$

The choice of items in an upper-limb measure is key, but these choices appear to be arbitrary in current measures; they are not drawn from a theoretical construct (or the construct has not been explained) or consultation with patients about the difficulties they have or their goals for treatment and in many cases fail to reflect contemporary activities or are specific to a particular country or culture (eg, using a kettle or shelling peas). None incorporate modern technologies, such as use of mobile telephones, texting, keyboards, and a mouse. These positively impact on ability to live independently, work, and communicate and are fundamental to many people's daily lives nowadays. Furthermore, most tools evaluate whether the pa- 
Table 3: Summary of the Psychometric Properties of Upper-Limb Measures (where available)

\begin{tabular}{|c|c|c|c|c|c|}
\hline & Groups Tested & Validity & $\begin{array}{l}\text { Test-Retest } \\
\text { Reliability }\end{array}$ & $\begin{array}{l}\text { Intertester } \\
\text { Reliability }\end{array}$ & $\begin{array}{c}\text { Ability to Detect } \\
\text { Change }\end{array}$ \\
\hline \multicolumn{6}{|l|}{$\begin{array}{l}\text { Upper-Limb Impairments-Hand (grips, grasps, } \\
\text { and dexterity) }\end{array}$} \\
\hline Fitts Reaching test ${ }^{45}$ & Stroke & ++ & +++ & & \\
\hline Box and Block test ${ }^{51 \dagger}$ & $\begin{array}{l}\text { Stroke, other pathologies } \\
\text { MS, TBI }\end{array}$ & +++ & +++ & +++ & $\mathrm{MDC}=6$ blocks \\
\hline Nine-Hole Peg Test ${ }^{46}$ & Stroke, MS & +++ & +++ & & $\mathrm{MDC}=32.8 \mathrm{~s}$ \\
\hline Action Research Arm Test ${ }^{52 \dagger}$ & Stroke & +++ & +++ & +++ & $\mathrm{MDC}=6$ \\
\hline \multicolumn{6}{|l|}{ Upper-Limb Activity in Everyday Life } \\
\hline Abilhand ${ }^{44}$ & Stroke & $++/+++$ & & & \\
\hline Motor Activity $\log ^{47}$ & Stroke & $++/+++$ & +++ & & \\
\hline Rivermead Motor Assessment-arm section ${ }^{48}$ & Stroke & $+/++$ & & & \\
\hline Motor Status Score 49 & Stroke & +++ & +++ & & \\
\hline Sollerman hand function test ${ }^{50}$ & Stroke & & +++ & +++ & \\
\hline Simplified STREAM-upper-limb section ${ }^{42}$ & Stroke & +++ & +++ & & \\
\hline
\end{tabular}

Abbreviations: +, weak; ++, moderate; +++, strong; MDC, minimal detectable change; MS, multiple sclerosis; TBI, traumatic brain injury. * Psychometric properties given star ratings based on criteria by Jørstad et al. ${ }^{21}$

${ }^{\dagger}$ Indicate those that had sufficient psychometric properties to recommend for use.

tient can do a task, rather than whether they do do it, or how much difficulty they have (the Motor Assessment Log, being the notable exception ${ }^{47}$ ). However, these issues are more relevant to patients and therefore need to be reflected in clinical measures of patient-centered treatment goals.

Another neglected area is activity for people with severe disabilities. Nearly all the measures focus on activities that require the patient to grip and transport or manipulate objects. Simpler activities that are relevant for people with severe impairments with little or no active function, such as being able to wash the weak arm and hand or get it into a sleeve or glove, are unaddressed. However, these are frequent goals of treatment and problems, which limit independence and impact on care needs for patients with severe impairments. A measurement tool that addresses passive activities and activities that do not involve grips and grasp of objects is urgently needed.

In the UK, the use of clinical outcome measures which are meaningful and important to patients is now a matter of health policy $^{59}$ and therefore the development of patient centered measures of upper-limb problems is a priority. To achieve this, research is needed to establish the constructs behind the rehabilitation of upper-limb problems, to consult with patients to identify activities important to them, and to design tools that enable the selection of individualized items while maintaining generalizability and comparison between individuals and groups.

A final issue limiting the evaluation of existing measures of upper-limb activity and their use in clinical practice is the inconsistent way in which several have been operationalized. This was demonstrated by a recent publication on the Action Research Arm Test, which attempted to give more detailed instructions on how to operationalize the assessment to minimize differences between assessors. ${ }^{54}$ Publications regarding the Wolf Motor Function Test ${ }^{32,60-64}$ and the Motor Activity $\log ^{47,65,66}$ have used different instructions to deliver the assessment and methods to calculate and analyze scores. These differences may be sufficient to affect the scores obtained to an extent that it prevents pooling of the data for meta-analysis and there is insufficient information to make a judgement about which are the most effective and should be used in clinical practice. In addition, the analysis of articles regarding the Wolf Motor Functional Test have used parametric analysis on the functional component despite this being an ordinal scale ${ }^{61}$; the mean and the log mean score for the scale and the 15 timed tasks have been used in analyses. ${ }^{63,67}$ The scale needs to undergo Rasch analysis with a calculation of logit values to convert the scores from ordinal to interval data before such analysis is meaningful or robust. ${ }^{68}$ For both tests, it would be helpful if the full operating instructions, including scoring and interpretation, were made available. Any variations on this method also need to be clearly articulated and justified.

\section{Study Limitations}

Like all systematic reviews, the quality of this review is dependent on the articles identified. Although we had thorough search strategies, we only included publications in English. There may have been relevant publications in other languages that we missed. We also did not attempt to identify unpublished data or the gray literature, so there may have been a publication bias in the data that we identified.

To the our knowledge, this is the first systematic review to specifically assess the clinical utility of upper-limb measurement tools. The system we developed to assess the utility was based on our clinical experience with consensus from neurologic physiotherapists, and the judgements of quality were arbitrary. Such judgements cannot be assumed to be appropriate for other health care systems or other areas of clinical practice. Nevertheless, they have strong face validity and were acceptable to neurologic physiotherapists working across the Northwest of England, who served a population of about 6.8 million people, so we feel they are reasonably generalizable.

\section{CONCLUSIONS}

The Box and Block and the Action Research Arm Tests produce robust data and are feasible for use in clinical practice. As the Action Research Arm Test clearly classifies the patients' level of ability and covers a wider range of ability than the Box and Block test it may be most appropriately used as a screening tool to establish the presence and severity of impairments, while the Box and Block test may be more appropriate to evaluate the outcome of treatment for patients who are able to make a grip. Future development of new or existing measures should ensure the construct and content of the measure is clearly identified and justified, standardized guidelines are easily available, and ensure it is individualized and contemporary. 
Development of a tool to measure passive function and activities which do not require the patient to be able to grip is also warranted.

\section{References}

1. American Occupational Therapy Association. Standards of practice for occupational therapy. Am J Occup Ther 2010;64:S106-111.

2. Chartered Society of Physiotherapy. Core standards of physiotherapy practice. London: Chartered Society of Physiotherapy; 2005.

3. College of Occupational Therapists. Professional standards for occupational therapy practice. London: College of Occupational Therapists; 2007.

4. Intercollegiate Stroke Working Party. National clinical guideline for stroke. 3rd ed. London: Royal College of Physicians; 2008.

5. The National Collaborating Centre for Chronic Conditions. Multiple sclerosis: national clinical guideline for diagnosis and management in primary and secondary care. London: Royal College of Physicians; 2004.

6. Royal College of Physicians and British Society of Rehabilitation Medicine. Rehabilitation following acquired brain injury: national clinical guidelines London: Royal College of Physicians and British Society of Rehabilitation Medicine; 2003.

7. Department of Health Long-Term Conditions National Services Framework Team. National services framework for long-term conditions. London: Department of Health; 2005.

8. Greenhalgh J, Tyson S, Long A, Flynn R. How do multidisciplinary teams use clinical outcome measures in clinical practice? Proceedings of the Society for Research in Rehabilitation Summer; London; 2006. Clin Rehabil 2006;20:1108.

9. Grimmer K, Bialocerkowski A, Kumar S, Milanese S. Implementing evidence in clinical practice: the therapies dilemma. Physiotherapy 2004;90:189-94.

10. Pollock A, Legg L, Langhorne P, Cellars S. Barriers to achieving evidence-based stroke rehabilitation. Clin Rehabil 2000;14:611-7.

11. Wade DT. Barriers to rehabilitation research, and overcoming them. Clin Rehabil 2003;17:1-4.

12. Kwakkel G, Wagenaar R, Koelman T, Lankhorst G, Koestier J. Effects of intensity of rehabilitation after stroke: a research synthesis. Stroke 1997;28:1550-6.

13. Doyle S, Bennett S, Fasoli S, McKenna K. Interventions for sensory impairment in the upper limb after stroke. Cochrane Database Syst Rev 2010 Jun 16;(6):CD006331.

14. Nichols-Larsen DS, Clark PC, Zeringue A, Greenspan A, Blanton S. Factors influencing stroke survivors' quality of life during subacute recovery. Stroke 2005;36:1480-4.

15. Ashford S, Slade M, Malaprade F, Turner-Stokes L. Evaluation of functional outcome measures for the hemiparetic upper limb: a systematic review. J Rehabil Med 2008;40:787-95.

16. Croarkin E, Danoff J, Barnes C, Croarkin E, Danoff J, Barnes C. Evidence-based rating of upper-extremity motor function tests used for people following a stroke. Phys Ther 2004;84:62-74.

17. Okkema KA, Culler KH. Functional evaluation of upper extremity use following stroke: a literature review. Top Stroke Rehabil 1998; 4:54-75.

18. Rowland TJ, Gustafsson L. Assessments of upper limb ability following stroke: a review. Br J Occup Ther 2008;71:427-37.

19. Tyson S, Connell L. The psychometric properties and clinical utility of measures of walking and mobility in neurological conditions: a systematic review. Clin Rehabi 2009;23:1018-33.

20. Tyson S, Connell L. How to measure balance activity in clinical practice? A systematic review of the psychometric properties and clinical utility of measurement tools for neurological conditions. Clin Rehabil 2009;23:824-40.

21. Jørstad EC, Hauer K, Becker C, Lamb SE. Measuring the psychological outcomes of falling: a systematic review. J Am Geriatr Soc 2005;53:501-10.
22. Sødring KM, Bautz-Holter E, Ljunggren AE, Wyller TB. Description and validation of a test of motor function and activities in stroke patients. The Sødring Motor Evaluation of Stroke Patients. Scand J Rehabil Med 1995;27:211-7.

23. Gowland C, Stratford P, Ward M, et al. Measuring physical impairment and disability with the Chedoke-McMaster Stroke Assessment. Stroke 1993;24:58-63.

24. Cohen JA, Fischer JS, Bolibrush DM, et al. Intrarater and interrater reliability of the MS functional composite outcome measure. Neurology 2000;54:802-6.

25. Fugl-Meyer A, Jääskö L, Leyman I, Olsson S, Steglind S. The post-stroke hemiplegic patient. Scand J Rehabil Med 1975;7:13-31.

26. Carroll D. A quantitative test of upper extremity function. J Chronic Dis 1965;18:479-91.

27. Sunderland A, Tinson D, Bradley L, Hewer R. Arm function after stroke. An evaluation of grip strength as a measure of recovery and a prognostic indicator. J Neurol Neurosurg Psychiatry 1989;52:126772.

28. Levin MF, Desrosiers J, Beauchemin D, Bergeron N, Rochette A. Development and validation of a scale for rating motor compensations used for reaching in patients with hemiparesis: the reaching performance scale. Phys Ther 2004;84:8-22.

29. Bernhardt J, Bate PJ, Matyas TA. Accuracy of observational kinematic assessment of upper-limb movements. Phys Ther 1998;78:25970 .

30. De Souza LH, Langton Hewer R, Miller S. Assessment of recovery of arm control in hemiplegic stroke patients. Arm function tests. Int Rehabil Med 1980;2:3-9.

31. Richards L, Stoker-Yates J, Pohl P, Wallace D, Duncan P. Reliability and validity of two tests of upper extremity motor function poststroke. Occup Ther J Res 2001;21:201-19.

32. Wolf SL, Catlin PA, Ellis M, Archer AL, Morgan B, Piacentino A. Assessing Wolf Motor Function Test as outcome measure for research in patients after stroke. Stroke 2001;32:1635-9.

33. Jebsen R, Taylor N, Trieschmann R, Trotter M, Howard L. An objective and standardised test of hand function. Arch Phys Med Rehabil 1969:50:311-9.

34. Bovend'Eerdt TJ, Dawes H, Johansen-Berg H, Wade DT. Evaluation of the Modified Jebsen Test of Hand Function and the University of Maryland Arm Questionnaire for Stroke. Clin Rehabil 2004;18:195202.

35. Kopp B, Kunkel A, Flor H, et al. The Arm Motor Ability Test: reliability, validity, and sensitivity to change of an instrument for assessing disabilities in activities of daily living. Arch Phys Med Rehabil 1997;78:615-20.

36. Green LB. Assessment of habitual physical activity and paretic arm mobility among stroke survivors by accelerometry. Top Stroke Rehabil 2007;14:9-21.

37. Uswatte G, Foo WL, Olmstead H, Lopez K, Holand A, Simms LB. Ambulatory monitoring of arm movement using accelerometry: an objective measure of upper-extremity rehabilitation in persons with chronic stroke. Arch Phys Med Rehabil 2005;86:1498-501.

38. Barreca S, Gowland CK, Stratford P, et al. Development of the Chedoke Arm and Hand Activity Inventory: theoretical constructs, item generation, and selection. Top Stroke Rehabil 2004;11:31-42.

39. Malouin F, Pichard L, Bonneau C, Durand A, Corriveau D. Evaluating motor recovery early after stroke: comparison of the FuglMeyer Assessment and the Motor Assessment Scale. Arch Phys Med Rehabil 1994;75:1206-12.

40. Hatanaka T, Koyama T, Kanematsu M, Takahashi N, Matsumoto K, Domen K. A new evaluation method for upper extremity dexterity of patients with hemiparesis after stroke: the 10-second tests. Int $\mathrm{J}$ Rehabil Res 2007:30:243-7.

41. Ahmed S, Mayo NE, Higgins J, Salbach NM, Finch L, WoodDauphinee SL. The Stroke Rehabilitation Assessment of Movement 
(STREAM): a comparison with other measures used to evaluate effects of stroke and rehabilitation. Phys Ther 2003;83:617-30.

42. Hsueh IP, Wang WC, Wang CH, et al. A simplified stroke rehabilitation assessment of movement instrument. Phys Ther 2006;86:93643.

43. World Health Organisation. ICF-Introduction, the International Classification of Functioning, Disability and Health. Geneva: World Health Organisation; 2001.

44. Penta M, Tesio L, Arnould C, Zancan A, Thonnard JL. The ABILHAND questionnaire as a measure of manual ability in chronic stroke patients: Rasch-based validation and relationship to upper limb impairment. Stroke 2001;32:1627-34.

45. Turton A, Fraser C. The use of a simple aiming task to measure recovery following stroke. Physiother Pract 1987;3:117-25.

46. Mathiowetz V, Weber K, Kashman N, Volland G. Adult norms for the Nine Hole Peg Test of finger dexterity. Occup Ther J Res 1985;5:24-37.

47. Uswatte G, Taub E, Morris D, Light K, Thompson PA. The Motor Activity Log-28: assessing daily use of the hemiparetic arm after stroke. Neurology 2006;67:1189-94.

48. Lincoln N, Leadbetter D. Assessment of motor function in stroke function. Physiotherapy 1979;65:48-51.

49. Ferraro M, Demaio JH, Krol J, et al. Assessing the motor status score: a scale for the evaluation of upper limb motor outcomes in patients after stroke. Neurorehabil Neural Repair 2002;16:283-9.

50. Brogardh C, Persson A, Sjolund B. Intra- and inter-rater reliability of the Sollerman hand function test in patients with chronic stroke. Disabil Rehabil 2007;29:145-54.

51. Mathiowetz V, Volland G, Kashman N, Weber K. Adult norms for the Box \& Block Test of manual dexterity. Am J Occup Ther 1985;39:386-91.

52. Lyle RC. A performance test for assessment of upper limb function in physical rehabilitation treatment and research. Int J Rehabil Res 1981;4:483-92.

53. Desrosiers J, Bravo G, Hebert R, Dutil E, Mercier L. Validation of the Box \& Block Test as a measure of dexterity of elderly people: reliability, validity, and norms studies. Arch Phys Med Rehabil 1994;75:751-5.

54. Yozbatiran N, Der-Yeghiaian L, Cramer SC. A standardized approach to performing the action research arm test. Neurorehabil Neural Repair 2008;22:78-90.

55. De Weerdt WJ, Harrison MA. Measuring recovery of arm-hand function in stroke patients: a comparison of the Brunnstrom-FuglMeyer test and the action research arm test. Physiother Can 1985;37: 65-70.

56. Lang CE, Wagner JM, Dromerick AW, Edwards DF. Measurement of upper-extremity function early after stroke: properties of the action research arm test. Arch Phys Med Rehabil 2006;87:1605-10.

57. Kiresuk T, Sherman R. Goal Attainment Scaling: a general measure of evaluating comprehensive mental health programs. Community Mental Health Journal 1968;4:443-53.

58. Baptiste S, Law M, Pollock N, Polatajko H, McColl MA, Carswell A. The Canadian Occupational Performance Measure. World Federation of Occupational Therapy Bulletin 1993;28:47-51.

59. Darzi, Professor the Lord Darzi of Denham. High quality care for all. NHS next stage review. Final report. London: Department of Health; 2008.

60. Bogard K, Wolf S, Zhang Q, Thompson P, Morris D, Nichols-Larsen D. Can the Wolf Motor Function Test be streamlined? Neurorehabil Neural Repair 2009;23:422-8.

61. Fritz SL, Blanton S, Uswatte G, Taub E, Wolf SL. Minimal detectable change scores for the Wolf Motor Function Test. Neurorehabil Neural Repair 2009;23:662-7.

62. Morris DM, Uswatte G, Crago JE, Cook IEW, Taub E. The reliability of the wolf motor function test for assessing upper extremity function after stroke. Arch Phys Med Rehabil 2001;82:750-5.
63. Wolf SL, Thompson PA, Morris DM, et al. The EXCITE trial: Attributes of the Wolf Motor Function Test in patients with subacute stroke. Neurorehabil Neural Repair 2005;19:194-205.

64. Whitall J, Savin DN Jr, Harris-Love M, Waller SM. Psychometric properties of a modified Wolf Motor Function test for people with mild and moderate upper-extremity hemiparesis. Arch Phys Med Rehabil 2006;87:656-60.

65. Uswatte G, Taub E, Morris D, Vignolo M, McCulloch K. Reliability and validity of the upper-extremity motor activity log-14 for measuring real-world arm use. Stroke 2005;36:2493-6.

66. van der Lee JH, Beckerman H, Knol DL, de Vet HC, Bouter LM. Clinimetric properties of the motor activity log for the assessment of arm use in hemiparetic patients. Stroke 2004;35:1410-4.

67. Wolf SL, McJunkin JP, Swanson ML, Weiss PS. Pilot normative database for the Wolf Motor Function Test. Arch Phys Med Rehabil 2006;87:443-5.

68. Tesio L. Measuring behaviours and perceptions: Rasch analysis as a tool for rehabilitation research. J Rehabil Med 2003;35:105-15.

69. Huxham F, Bate P, Morris M. Disorders of upper limb speed and accuracy following stroke. Physiotherapy Singapore 2001;4:15-22.

70. Boissy P, Bourbonnais D, Carlotti MM, Gravel D, Arsenault BA. Maximal grip force in chronic stroke subjects and its relationship to global upper extremity function. Clin Rehabil 1999;13:354-62.

71. Desrosiers J, Herbert R, Dutil E, Bravo G, Mercier L. Validity of the TEMPA: a measurement instrument for upper extremity performance. Occup Ther J Res 1994;14:267-81.

72. Platz T, Pinkowski C, van Wijck F, Kim IH, di Bella P, Johnson G. Reliability and validity of arm function assessment with standardized guidelines for the Fugl-Meyer Test, Action Research Arm Test and Box \& Block Test: a multicentre study. Clin Rehabil 2005;19:404-11.

73. Chen HM, Chen CC, Hsueh IP, Huang SL, Hsieh CL. Test-retest reproducibility and smallest real difference of 5 hand function tests in patients with stroke. Neurorehabil Neural Repair 2009;23:435-40.

74. Feys P, Duportail M, Kos D, Van Asch P, Ketelaer P. Validity of the TEMPA for the measurement of upper limb function in multiple sclerosis. Clin Rehabil 2002;16:166-73.

75. Van der Lee JH, Beckerman H, Lankhorst GJ, Bouter LM. The responsiveness of the Action Research Arm test and the Fugl-Meyer Assessment scale in chronic stroke patients. J Rehabil Med 2001;33: 110-3.

76. Van der Lee JH, De Groot V, Beckerman H, Wagenaar RC, Lankhorst GJ, Bouter LM. The intra- and interrater reliability of the action research arm test: a practical test of upper extremity function in patients with stroke. Arch Phys Med Rehabil 2001;82:14-9.

77. Hsieh CL, Hsueh IP, Chiang FM, Lin PH. Inter-rater reliability and validity of the action research arm test in stroke patients. Age Ageing 1998;27:107-14.

78. $\mathrm{Ng} \mathrm{AK}$, Leung DP, Fong KN. Clinical utility of the action research arm test, the wolf motor function test and the motor activity log for hemiparetic upper extremity functions after stroke: a pilot study. Hong Kong Journal of Occupational Therapy 2008;18:20-7.

79. Rabadi M, Rabadi F. Comparison of the action research arm test and the Fugl-Meyer assessment as measures of upper-extremity motor weakness after stroke. Arch Phys Med Rehabil 2006;87:962-6.

80. Kurtaiş Y, Küçükdeveci A, Elhan A, et al. Psychometric properties of the Rivermead Motor Assessment: its utility in stroke. J Rehabil Med 2009;41:1055-61.

81. Collin C, Wade D. Assessing motor impairment after stroke: a pilot reliability study. J Neurol Neurosurg Psychiatry 1990;53:576-9.

82. Hsueh IP, Hsu MJ, Sheu CF, Lee S, Hsieh CL, Lin JH. Psychometric comparisons of 2 versions of the Fugl-Meyer Motor Scale and 2 versions of the Stroke Rehabilitation Assessment of Movement. Neurorehabil Neural Repair 2008;22:737-44. 